\title{
Elucidating the multifunctional role of the cell wall components in the maize exploitation
}

\author{
Ana López-Malvar ${ }^{1,2 *}$, Rosa Ana Malvar ${ }^{3}$, Xose Carlos Souto ${ }^{4}$, Leonardo Dario Gomez ${ }^{5}$, Rachael Simister ${ }^{5}$, \\ Antonio Encina ${ }^{6}$, Jaime Barros-Rios ${ }^{7}$, Sonia Pereira-Crespo ${ }^{8}$ and Rogelio Santiago ${ }^{1,2}$
}

\begin{abstract}
Background: Besides the use of maize grain as food and feed, maize stover can be a profitable by-product for cellulosic ethanol production, whereas the whole plant can be used for silage production. However, yield is reduced by pest damages, stem corn borers being one of the most important yield constraints. Overall, cell wall composition is key in determining the quality of maize biomass, as well as pest resistance. This study aims to evaluate the composition of the four cell wall fractions (cellulose, hemicellulose, lignin and hydroxycinnamates) in diverse maize genotypes and to understand how this composition influences the resistance to pests, ethanol capacity and digestibility.
\end{abstract}

Results: The following results can be highlighted: (i) pests' resistant materials may show cell walls with low p-coumaric acid and low hemicellulose content; (ii) inbred lines showing cell walls with high cellulose content and high diferulate cross-linking may present higher performance for ethanol production; (iii) and inbreds with enhanced digestibility may have cell walls poor in neutral detergent fibre and diferulates, combined with a lignin polymer composition richer in G subunits.

Conclusions: Results evidence that there is no maize cell wall ideotype among the tested for optimal performance for various uses, and maize plants should be specifically bred for each particular application.

Keywords: Maize, Saccharification, Digestibility, Pest resistance, Cell wall

\section{Background}

Accessibility, extensibility, and digestibility of tissues would determine important characteristics of maize, such as resistance to stem borers, stem diseases, feedstuff quality and saccharification for ethanol production. These characteristics depend on the cell wall composition and structure [1]. Genetic variation for resistance to corn borers [2], for cell wall composition and degradability [3], and for ethanol production [4] has been identified in maize.

\footnotetext{
*Correspondence: alopezmalvar@uvigo.es

${ }^{1}$ Facultad, de Biología, Departamento de Biología Vegetal Y Ciencias del Suelo, Universidad de Vigo, As Lagoas Marcosende, 36310 Vigo, Spain Full list of author information is available at the end of the article
}

Maize inbred lines have different mechanisms of defence (i.e. morphological plant traits, antibiotic compounds, cell wall stiffening, etc.) that determine the level of corn borer resistance in a particular inbred line [5]. Similarly, saccharification yields or cell wall degradability depend on the cell wall composition and properties of the inbred line, and their response to pre-treatment and hydrolysis [6]. Therefore, it seems that different genotypes may have different defence mechanisms, react differently to pre-treatment, and have different cell wall properties that facilitate saccharification or digestibility.

Maize breeding strategies are normally focused on a particular trait (pest resistance, digestibility or ethanol production) that produce indirect effects on cell wall 
components. For example, recurrent selection to improve resistance to corn borer attack increases cell wall bound hydroxycinnamates concentration in the pith tissues of the improved maize cycles [7]. Buendgen et al. [8] recorded increases in neutral and acid detergent fibres values (NDF, ADF) and lignin content in the leaf sheath and stalks of maize after five cycles of selection for first and second generation European Corn Borer resistance. Similarly, Bergvinson et al. [9] found increases in diferulic acid concentration over diverse cycles of selection to increase corn borer resistance.

In switchgrass, Sarath et al. [10] studied divergent breeding generations for high or low in vitro dry matter digestibility (IVDMD). This selection resulted in populations differing in lignin concentration and acid detergent fibre. Plants from these two populations also displayed different cell wall composition and accessibility to hydrolytic enzymes [11], which led to an increase in the net mean ethanol yields in plants selected for increased IVDMD. Similarly, after six generations of divergent breeding for forage IVDMD on switchgrass, Vogel et al. [12] observed differences between populations cell wall fibres, lignin content matrix polysaccharides and esterified ferulates. In the same way, selection for improved saccharification efficiency in alfalfa stems produced increases in glucose release and a reduced lignin content in the lines selected [13].

Direct changes towards cell wall structure can also influence the final uses of maize. Successful divergent selection for diferulate ester content in the maize pith resulted in changes in cell wall composition [14]. These changes led to cell wall stiffening, which is the main deterrent of corn borer attack and development. However, the increase in diferulate esters was associated with a decrease in glucose concentration [15]. Furthermore, increasing diferulate content in the maize pith impact negatively in cell wall degradability properties. Jung et al. [16] studied the effect of ferulate crosslinking on dry matter intake, milk production potential and in vivo digestibility for silage maize using the low ferulate seedling ferulate ester ( $s f e$ ) mutant. Lines presenting the mutation showed reduced ether ferulate crosslinking of lignin to arabinoxylans. Cattle fed with this mutant showed greater dry matter intake and milk production.

A final approach to investigate the relationship between cell wall and maize uses consists in mutant or transgenic evaluations. Brown midrib mutants ( $b m$ 1-4) have been an excellent material to study digestibility and lignification [17]. These mutants have favourable phenotypic traits such as decreased lignin concentration, shift in lignin composition and modified ratio of esterified phenolics. This change in cell wall composition produces higher digestibility and a higher rate of ingestion when fed to cattle [18]. Furthermore, modifications of the phenylpropanoid pathway, through up and downregulation of enzymes directly influencing lignin content and monolignol composition, have been associated with increases in saccharification efficiency in several crops. For example, transgenic switchgrass lines with reduced Cinnamyl Alcohol Dehydrogenase (CAD) levels and consequently reduced lignin content and altered lignin composition, showed improved sugar release and forage digestibility [19].

Considering that limited cell wall components have been tested in specific and limited studies, the aim of the current study is to extensively characterize the cell wall composition and the performance of maize genotypes for different applications using the same experimental trials. The present work has the advantage of including an extensive characterization of the cell wall in a genetically diverse selection of 20 inbred lines. This would help us to confirm previously established relationships in more limited genetic environments. The composition of the cell wall (cellulose, hemicellulose, lignin and hydroxycinnamates) was determined in all inbred lines, and the aptitude for different uses (forage digestibility, ethanol production, digestibility and saccharification) was evaluated.

The main objective of this research is to know the composition of the four cell wall fractions in different maize genotypes and elucidate how this composition influences pest resistance $(R)$, ethanolic production (E) and forage digestibility (D). Those last three aspects will be further on denoted as R.E.D.

\section{Methods}

\section{Plant material}

A set of 20 inbred lines was evaluated (Table 1). These inbreds were divided into groups according to the reason they were included in the panel set:

1. The first subset of inbred lines includes maize inbreed lines that have been characterised in relation to resistance to corn borer attack [2]. Among these inbred lines there are susceptible (EP42, EP47) and resistant (EP17, EP53, EP105, EP125, EP86, F473, PB130, A509) lines. The resistant group (with the exception of EP105) was composed by seven of the eight founders of a Multi-Parent Advanced Generation InterCross (MAGIC) population [20-22]. EP105 derived from the cross A671 x A295 to obtain reduced tunnel length [23]. Lines that are resistant to corn borer attack, show distinct defence mechanisms [24]. This subset of inbred lines was obtained and granted by Mision Biológica de Galicia's germplasm bank.

2. The second subset includes five inbred lines from the Agriculture and Agri-Food Canada (AAFC): C103, CO384, CO348, CO442 and CO444. Inbred 
Table 1 Description (grain type and colour, pedigree, research interest) of the inbred lines included in the experimental set

\begin{tabular}{|c|c|c|c|c|}
\hline Inbred line & Germplasm group & Grain colour and type & Pedigree & Research interest \\
\hline EP17 & European & $\begin{array}{l}\text { - Yellow } \\
\text { - Flint }\end{array}$ & J.L. Blanco (A1267) & $\begin{array}{l}\text { - Parent MAGIC population } \\
\text { - Corn borer resistant }\end{array}$ \\
\hline EP42 & European & $\begin{array}{l}\text { - Yellow } \\
\text { - Flint }\end{array}$ & Tomiño. Spanish Landrace & - Corn borer susceptible \\
\hline EP47 & Longfellow & $\begin{array}{l}\text { - Yellow } \\
\text { - Flint }\end{array}$ & $(E P 4 \times A 239) E P 4$ & - Corn borer susceptible \\
\hline EP53 & European & $\begin{array}{l}\text { - Yellow } \\
\text { - Flint }\end{array}$ & Laro. Spanish Landrace & $\begin{array}{l}\text { - Parent MAGIC population } \\
\text { - Corn borer resistant }\end{array}$ \\
\hline EP105 & Lancaster & $\begin{array}{l}\text { - Yellow } \\
\text { - Dent }\end{array}$ & A671XA295 & - Corn borer resistant \\
\hline EP125 & Corn Belt & $\begin{array}{l}\text { - Yellow } \\
\text { - Dent }\end{array}$ & Seleccion of CO125. Wisc. exp. single cross & $\begin{array}{l}\text { - Parent MAGIC population } \\
\text { - Corn borer resistant }\end{array}$ \\
\hline EP86 & European & $\begin{array}{l}\text { - Yellow } \\
\text { - Flint }\end{array}$ & Nostrano dell'Isola. Italian Landrace & $\begin{array}{l}\text { - Parent MAGIC population } \\
\text { - Corn borer resistant }\end{array}$ \\
\hline F473 & European & $\begin{array}{l}\text { - White } \\
\text { - Flint }\end{array}$ & Doré de Gomer. French Landrace & $\begin{array}{l}\text { - Parent MAGIC population } \\
\text { - Corn borer resistant }\end{array}$ \\
\hline PB130 & European & $\begin{array}{l}\text { - Yellow } \\
\text { - Flint }\end{array}$ & Rojo vinoso de Aragón. Spanish Landrace & $\begin{array}{l}\text { - Parent MAGIC population } \\
\text { - Corn borer resistant }\end{array}$ \\
\hline A509 & Corn Belt & $\begin{array}{l}\text { - Yellow } \\
\text { - Dent }\end{array}$ & $\mathrm{A} 78 \times \mathrm{A} 109$ & $\begin{array}{l}\text { - Parent MAGIC population } \\
\text { - Corn borer resistant }\end{array}$ \\
\hline $\mathrm{CO} 348$ & Tropical & $\begin{array}{l}\text { - Yellow } \\
\text { - Flint }\end{array}$ & CIMMYT-NTR-2 & $\begin{array}{l}\text { - Sugar corn ethanol hybrids } \\
\text { - Moderate Fusarium stalk rot resistance }\end{array}$ \\
\hline C103 & Lancaster & $\begin{array}{l}\text { - Yellow } \\
\text { - Dent }\end{array}$ & Lancaster & - High stalk sucrose inbred \\
\hline $\mathrm{CO} 384$ & Reid & $\begin{array}{l}\text { - Yellow } \\
\text { - Flint }\end{array}$ & $\mathrm{A} 632 \times \mathrm{CO} 255$ & - Parent of sugar corn ethanol hybrids \\
\hline $\mathrm{CO} 442$ & lodent & - Flint-Dent & lodent/NSS & - Parent of sugar corn ethanol hybrids \\
\hline $\mathrm{CO} 444$ & Lancanster-European & $\begin{array}{l}\text { - Yellow } \\
\text { - Flint-Dent }\end{array}$ & $\mathrm{S} 1381 \times \mathrm{CO} 382$ & $\begin{array}{l}\text { - Parent of sugar corn ethanol hybrids } \\
\text { - Lodging resistance }\end{array}$ \\
\hline EC212 & European & $\begin{array}{l}\text { - Yellow } \\
\text { - Flint }\end{array}$ & European Germplasm & $\begin{array}{l}\text { - High degradability } \\
\text { - Good general combining ability (GCA) }\end{array}$ \\
\hline A654 & Reid & $\begin{array}{l}\text { - Yellow } \\
\text { - Dent }\end{array}$ & A116 $\times$ WF9 & - Good GCA \\
\hline W182B & Reid & $\begin{array}{l}\text { - Yellow } \\
\text { - Dent }\end{array}$ & $\mathrm{WD} \times \mathrm{W} 22$ & - Good GCA \\
\hline A632 & Reid & $\begin{array}{l}\text { - Yellow } \\
\text { - Dent }\end{array}$ & $(\mathrm{M}+42 \times \mathrm{B} 14) \mathrm{B} 143$ & - Reid Germplasm Group \\
\hline W64A & Reid & $\begin{array}{l}\text { - Yellow } \\
\text { - Dent }\end{array}$ & WF9 $\times$ C.I.187-2 & - Corn Borer resistant \\
\hline
\end{tabular}

C103 has high concentration of sucrose in the stalk. Reid et al. [25] developed hybrids combinations using $\mathrm{C} 103$ as male with $\mathrm{CO} 348, \mathrm{CO} 384, \mathrm{CO} 442$ and $\mathrm{CO} 444$. Authors proposed the usage of these hybrids for ethanol production and biomass for silage, and they are known as "Sugarcorn Hybrids". This subset of inbred lines was obtained and granted by Dr. Lana Reid from the Eastern Cereal and Oilseed Research Centre in Canada.

3. The last group was formed by inbred lines with good performance in hybrid combination. Inbred EC212 has very good general and specific combinatorial aptitude for high animal digestibility [26]. This group was completed with inbreds A654 and W182B, both belonging to the Reid germplasm group. The hybrid combination attending to heterotic patterns is well stablished in maize; in this case, we would expect good hybrid combinations with the MAGIC inbred parents, these not belonging to Reid germplasm. The inbred EC212 was granted by Dr. Jesus Moreno from the CIAM's germplasm bank in Mabegondo and A654 and W182 by Misión Biologica de Galicia's germplasm bank.

\section{Field experimental design}

The inbred panel was evaluated in 2016 and 2017 in Pontevedra, in North Western Spain $\left(42^{\circ} 25^{\prime} \mathrm{N}, 8^{\circ} 38^{\prime} \mathrm{W}\right.$ and $20 \mathrm{~m}$ above sea level). A random block design with three 
repetitions was used in the two trials. The second year, the subset of inbred lines was reduced to nineteen due to the lack of seed for the inbred PB130. Each experimental plot consisted of three rows, each row with 15 doublekernel hills planted manually, spacing between consecutive hills in a row being $0.18 \mathrm{~m}$ and $0.8 \mathrm{~m}$ between rows, obtaining a final density of $\sim 70,000$ plants $\mathrm{ha}^{-1}$ after thinning. Local agronomical practices were fulfilled.

\section{Agronomic traits}

Por each plot, the days from planting to the date when half of the plants shed pollen or showed silks were recorded as days to anthesis or silking, respectively. Grain and stover yields were recorded at harvest (approx. 70 days after silking); meanwhile forage yield that was recorded 55 days after silking.

\section{Grain yield}

Grain yield was calculated with the weight of ears collected in a plot and expressed in $\mathrm{Mg} \mathrm{ha}^{-1}$ at $14 \%$ humidity. It was determined by the following equation:
As for grain yield, yields were calculated per plant and then transformed to $\mathrm{Mg} / \mathrm{ha}$.

\section{Cell wall biochemical characterization}

The second internode below the main ear was collected from five plants in each plot. Samples were collected 55 days after silking. Each harvested internode was frozen at $-20{ }^{\circ} \mathrm{C}$ until analytical determinations. Then, samples were dried at $60{ }^{\circ} \mathrm{C}$ and ground in a Wiley (Arthur $\mathrm{H}$. Thomas, Philadelphia, PA) mill with a $0.75 \mathrm{~mm}$ screen before being analysed.

Determinations were based in whole dry internode tissues unless mentioned otherwise. Some other biochemical traits (cellulose, total and neutral sugars, uronic acids, and lignin monomeric composition) were determined in isolated cell walls from those internodes following the cell wall isolation protocol modified by Melida et al. [27].

$$
\text { Grain Yield }\left(\frac{M g}{h a}\right)=\frac{\text { Plot ear weight }(\mathrm{kg}) \times(100-\text { Humidity }) \times \text { Grain weight of } 5 \text { ears }(g)}{\text { Number of plants } \times 0.8 \times 0.18(m 2) \times 8.6 \times \text { Total weight of } 5 \text { ears }(g)}
$$

where humidity, expressed as a percentage, was recorded using a moisture meter Kett (model PM-400) in a sample of $240 \mathrm{~cm}^{3}$.The value 8.6 on the equation corresponds to a constant to adjust the yield at $14 \%$ humidity. Therefore, yield was calculated per plant and then transformed to $\mathrm{Mg} \mathrm{ha}^{-1}$.

\section{Stover and forage yield}

In each plot, the weight of 2-10 plants without ears (weight of fresh stover) was recorded, and a stover sample was collected for estimating the percentage of stover dry matter and saccharification efficiency analyses. The fresh stover sample was weighed (sample fresh weight), chopped, pre-dried at $35{ }^{\circ} \mathrm{C}$ in a forced air camera, dried at $60{ }^{\circ} \mathrm{C}$ in a stove and again weighed after seven days (sample dry weight). Dry stove samples from each plot were grounded in a Wiley mill with a $0.75 \mathrm{~mm}$ screen for saccharification assays. Forage yield and forage dry matters were similarly computed but using complete plants collected 55 days after silking.

Stover and forage yields in $\mathrm{Mg}$ of dry matter ha ${ }^{-1}$ were determined by the following equation:

\section{Cellulose quantification}

Cellulose was quantified by the Updegraff method [28]. The concentration of cellulosic sugars was assessed by the method of the anthrone [29] using glucose as standard.

\section{Hemicellulose}

For total, and neutral sugars and uronic acids, $5 \mathrm{mg}$ of tissue were weighed and hydrolysed at $212{ }^{\circ} \mathrm{C}$ by adding $2 \mathrm{ml}$ of $2 \mathrm{M}$ trifluoroacetic acid (TFA) for $1 \mathrm{~h}$. Total sugar content was determined by the phenol-sulphuric method using glucose as standard [30]. Uronic acid contents were determined by the m-hydroxybiphenyl method [31], with glucuronic acid as a standard. Monosaccharide composition of the matrix polysaccharides was performed in whole dry tissues samples using high performance anion exchange chromatography (HPAEC) (Carbopac PA-10; Dionex, Camberley, Surrey, UK) as described previously by Jones et al. [32].

$$
\text { Stover/forage yield }\left(\frac{M g}{h a}\right)=\frac{\text { weigth of plants }(g) * \text { sample dry weigth }(g)}{\text { Number of plants } \times 0.8 \times 0.18 * \text { sample fresh weight }(g) \times 100}
$$




\section{Lignin content and lignin monomeric composition}

Total lignin content was determined by Klason Lignin protocol [33]. Monomer composition was determined by thioacidolysis followed by Gas chromatography-mass spectrometry (GC-MS) [34]. The thioacidolysis procedure estimates the proportion of lignin subunits linked by the major $\beta-O-4$ linkages.

\section{Hydroxycinnamates}

A recently optimized protocol by Santiago and col. [35] was used for cell wall bound hydroxycinnamates quantification [35]. Phenolic standards ferulic acid (FA) and $p$-coumaric acid (PCA) were purchased from SigmaAldrich Quimica SL, Madrid, Spain Sigma. The identities of FA dimers were confirmed by a comparison with $5-5$ standard or published retention times and UV spectra [36]. The total diferulate content (DFAT) was calculated as the sum of the following three identified and quantified DFA isomers: DFA 8-O-4, DFA 5-5-, and DFA 8-5. The DFA 8-5 concentrations were calculated as the sum of 8-5-cyclic (or benzofuran)-DFA and 8-5-noncyclic (or open).

\section{Fibres composition}

Neutral Detergent Fibre (NDF) and Acid Detergent Fibre (ADF) were determined by Near-Infrared Spectroscopy (NIRs). We included a new variation in the hemicellulose estimation using the hemicellulose content in the fibres, as the difference between ADF and NDF. We will refer to this determination in the text as hemicellulose quantified as percentage (\%). The spectral information of the dried and grounded $(1 \mathrm{~mm})$ samples was obtained using a Foss NIRSystem 6500 monochromator spectrophotometer (Foss NIRSystem, Silver Spring, Washington, USA), located in an isothermal chamber $\left(24 \pm 1^{\circ} \mathrm{C}\right)$, provided with a rotation module that performs reflectance measurements in the spectral region between 400 and $2500 \mathrm{~nm}$, at $2 \mathrm{~nm}$ intervals. The collection of the spectral data and the chemometric analysis of the data was carried out using the WinISI II v program. 1.5 (Infrasoft International, Port Matilda, PA, USA). In order to detect the presence of extrapolations of the prediction model, the identification of "outliers" samples (spectra not represented within the available NIRS calibration group) was performed using the Mahalanobis $(\mathrm{GH})$. Those samples that presented $\mathrm{GH}$ values greater than 3, were selected indicating that the sample did not belong to the calibration group [37]. The samples recognized as outliers were analysed by reference methods in the LIGAL laboratory. Subsequently, the reference values were integrated into the corresponding spectral library of the calibration group, expanding and updating the NIRS prediction equations. The outlier samples were analysed in duplicated by wet determinations using reference methods. NDF and ADF were carried out following the procedures proposed by Van Soest and Robertson [38] for NDF, and by Goering and Van Soest [39] for ADF, adapted to the Fibretec System model 1020 digester (Foss Tecator AB, Höganäs, Sweden).

\section{Saccharification efficiency}

Saccharification assays were performed as described in Gómez et al. [40]. Samples were pre-treated with $0.5 \mathrm{M}$ $\mathrm{NaOH}$ at $90^{\circ} \mathrm{C}$ for $30 \mathrm{~min}$, washed four times with $500 \mu \mathrm{l}$ sodium acetate buffer and subjected to enzymatic digestion (Celluclast CTec2, 7FPU/g) at $50{ }^{\circ} \mathrm{C}$ for $8 \mathrm{~h}$. The amount of released sugars $\left(\mathrm{nmol} \mathrm{mg} \mathrm{material}^{-1} \mathrm{~h}^{-1}\right.$ ) was assessed against a glucose standard curve using the 3-methyl-2-benzothiazolinone hydrozone method.

\section{Digestibility of the organic matter}

Digestibility of the Organic Matter (DOM) of the internode was also determined by Near-infrared spectroscopy (NIRs) at LIGAL. The spectral information of the dried and grounded $(1 \mathrm{~mm})$ samples was obtained in the same way reported for fibres estimations. The samples recognized as outliers were analysed by the in vitro digestibility procedure described by Tilley and Terry, [41] modified by Alexander and McGowan [42].

\section{Statistical analysis \\ Analysis of variance}

Individual and combined analyses of variance were made for each trait according to the SAS mixed model procedure (PROC MIXED) of the SAS program (version 9.4) [43], except for DOM and fibres as those estimates were un-replicated. The best linear unbiased estimators (BLUES) for each inbred line were calculated based on the combined data for the 2-year analysis. Inbred lines were considered as the fixed effects, while years, replication within years, and lines $\times$ year were considered random effects. The comparison of means among inbred lines was carried out using the Fisher's protected least significant difference (LSD.

\section{Correlation analysis}

Correlation coefficients between R.E.D traits and yield (grain, stover, and forage yields) were calculated using REML estimates according to a published SAS mixed model procedure [43].

\section{Contrast analysis}

After the variance analysis, the inbred lines were classified in high and low groups according to saccharification efficiency. For digestibility of organic matter, lines were classified qualitatively. The inbred lines were also 
classified by its resistance or susceptibility to corn borer attack based on previous evaluations of these materials [2]. Resistance to corn borer has been associated to lower tunnel length of galleries. In this case, the groups were only formed by 5 inbred lines in accordance to the results obtained in previous evaluations [2]. With this new dataset, means comparison were performed in order to determine the existence of significant differences in cell wall composition between high and low groups.

\section{Multiple linear regression analysis}

In order to understand the relationship between cell wall components and the economically important uses of maize (R.E.D), multiple linear regression models were built for saccharification efficiency and DOM using the cell wall components as probable predictors. The stepwise method following the PROC REG procedure in SAS was used [43]. Only the variables with a significance value less than 0.15 were selected.

\section{Results}

\section{Analysis of variance and means comparisons Agronomic traits}

The subset of inbred lines evaluated showed variation for all the agronomic traits tested (Supplementary Table 1). Inbred lines also differed for grain, forage and stover yields. Year $\mathrm{x}$ inbred interaction was only significant for grain yield (data not shown.

\section{Cell wall composition}

The inbred lines included in this study showed differences in cellulose, lignin, and hydroxycinnamates, but not in hemicellulose. Regarding lignin polymer, we found variation not only for lignin content (Klason Lignin), but also for lignin monomeric composition (Supplementary Table 2-5). Variation for hydroxycinnmamic acids among the inbred lines was except for FA whose $p$-value (0.06) was, however, close to the significance level (Supplementary Table 4).

Inbreds only showed significant differences for one hemicellulose related trait, neutral sugars concentration, but genotype $\times$ environment interactions were significant for uronic acids, total sugars and arabinose:xylose ratio. We did not find variation for monosaccharide composition among the 20 genotypes evaluated.

\section{R.E.D traits}

There was large variability for all traits of economic importance. Within trials involving the final use of maize, inbred lines differed significantly for saccharification efficiency ranging from $85.98 \mathrm{nmol} \mathrm{mg}^{-1}$ material $^{-1} \mathrm{~h}^{-1}$ in the inbred CO384 to $107.72 \mathrm{nmol} \mathrm{mg}^{-1}$ material $^{-1} \mathrm{~h}^{-1}$ in the line F473 (Supplementary Table 6). DOM values varied from $53.4 \%$ to $63.8 \%$. There were not significant differences among the inbreds for tunnel length.

\section{Correlations between R.E.D. and yield traits}

Correlations between yield traits and R.E.D were performed in order to assess the covariation among traits. Only significant correlations above 0.50 in absolute values are described, but the complete set of correlations is shown in Table 2 . The only strong correlation among those traits was observed between stover and forage yields $\left(r_{\mathrm{p}}=0.66\right)$.

\section{Contrast and multiple linear regression analysis}

To understand the relationship between cell wall components and economically important uses of maize, we performed contrast analysis and multiple linear regression analysis. With the data from the analysis of variance, and the previous data for tunnel length, we classified inbred lines in High, Intermediate and Low for the contrast analysis (Tables 3 and 4). For the multiple linear regression models, we analysed saccharification efficiency and DOM as dependent variables. Model for each variable are shown in Table 5.

Overall, susceptible inbred lines presented higher concentration of hemicellulose and $p$-coumaric acid than resistant inbred lines. Differences between high and low saccharification efficiency groups (E.) were significant for ferulic acid dimers concentration which were larger in the high saccharification efficiency group. Supporting these results, in the multiple linear regression analysis, we identified cellulose and DFA 8-5-b as significantly involved in the variability for saccharification. Regarding to forage feedstocks (D.), highly degradable lines presented lower concentrations of PCA, DFA 5-5, DFA 8-5-1 and DFAT, lower proportion of glucuronic acid, and greater proportions of $G$ subunits. In addition, we obtained in the multiple regression model that DOM was negatively affected by the content in NDF, whereas positively affected by FA and $\mathrm{G}$ subunits.

Table 2 Phenotypic correlation for R.E.D and yield traits and correlation values using a particular internode or the whole plant material evaluated in 20 inbred lines during two years

\begin{tabular}{lccll}
\hline & SACC & DOM & Grain yield & Forage yield \\
\hline SACC & & & & \\
DOM & 0.001 & & & \\
Grain yield & 0.16 & 0.07 & & \\
Forage yield & 0.00 & 0.32 & 0.34 & 0.66 \\
Stover yield & -0.01 & 0.42 & 0.15 & \\
\hline
\end{tabular}

SACC Saccharification efficiency (nmol mg material ${ }^{-1} \mathrm{~h}^{-1}$, DOM Digestibility of the organic matter (\%); Grain, Forage and stover yield $(\mathrm{Mg} / \mathrm{h})$ 
Table 3 Classification of the inbred lines according to the mean values they presented for R.E.D traits evaluated in two years

\begin{tabular}{|c|c|c|c|}
\hline Inbred line & $\begin{array}{l}\text { Saccharification } \\
\text { efficiency }\end{array}$ & $\begin{array}{l}\text { Digestibility of } \\
\text { organic matter }\end{array}$ & Tunnel length \\
\hline A509 & Intermediate & Low & Intermediate \\
\hline A632 & Intermediate & Intermediate & Low \\
\hline A654 & High & Intermediate & Low \\
\hline C103 & Low & High & Intermediate \\
\hline $\mathrm{CO} 348$ & Intermediate & High & Low \\
\hline $\mathrm{CO} 384$ & Low & High & Intermediate \\
\hline $\mathrm{CO} 442$ & High & Intermediate & Intermediate \\
\hline $\mathrm{CO} 444$ & Low & Intermediate & High \\
\hline EC2High2 & High & High & Intermediate \\
\hline EP105 & Intermediate & Intermediate & Intermediate \\
\hline EP125 & Low & Low & Low \\
\hline EP17 & High & Intermediate & Intermediate \\
\hline EP42 & High & High & High \\
\hline EP47 & Intermediate & Intermediate & High \\
\hline EP53 & Low & Low & Intermediate \\
\hline EP86 & Intermediate & Low & High \\
\hline F473 & High & Low & Intermediate \\
\hline PB13I0 & Intermediate & High & Low \\
\hline W182B & Low & Low & High \\
\hline W64A & Intermediate & Intermediate & Intermediate \\
\hline
\end{tabular}

Table 4 Contrast analysis for the high and low groups of inbred lines classified attending to R.E.D traits. Means for cell wall components with significant differences among groups are included

\begin{tabular}{lccc}
\hline & \multicolumn{3}{c}{ Classification group } \\
\cline { 2 - 4 } CW component & High & Low & LSD \\
\hline Tunnel length (cm) & & \\
PCA (mg/g) & $13.10^{\mathrm{a}}$ & $12.27^{\mathrm{b}}$ & 0.777 \\
Hemicellulose (\%) & $30.2^{\mathrm{a}}$ & $29.5^{\mathrm{b}}$ & 0.5 \\
Saccharification efficiency & $\left(\mathbf{n m o l} \mathbf{m g}^{\text {material }} \mathbf{- 1}^{-1} \mathbf{h}^{-1}\right)$ & \\
DFA 8-O-4 (mg/g) & $0.088^{\mathrm{a}}$ & $0.065^{\mathrm{b}}$ & 0.015 \\
DFA 8-5-b (mg/g) & $0.116^{\mathrm{a}}$ & $0.089^{\mathrm{b}}$ & 0.015 \\
DFA 8-5 (mg/g) & $0.017^{\mathrm{a}}$ & $0.014^{\mathrm{b}}$ & 0.017 \\
DFAT (mg/g) & $0.350^{\mathrm{a}}$ & $0.274^{\mathrm{b}}$ & 0.041 \\
Digestibility of the organic matter (\%) & & \\
PCA (mg/g) & $10.72^{\mathrm{a}}$ & $13.94^{\mathrm{b}}$ & 0.991 \\
DFA 8-5-I (mg/g) & $0.042^{\mathrm{a}}$ & $0.060^{\mathrm{b}}$ & 0.010 \\
DFA 8-5 (mg/g) & $0.125^{\mathrm{a}}$ & $0.164^{\mathrm{b}}$ & 0.013 \\
DFAT (mg/g) & $0.255^{\mathrm{a}}$ & $0.320^{\mathrm{b}}$ & 0.017 \\
G (\%) & $40.42^{\mathrm{a}}$ & $39.27^{\mathrm{b}}$ & 0.852 \\
GLUA (mg/g) & $2.46^{\mathrm{a}}$ & $3.43^{\mathrm{b}}$ & 0.55 \\
\hline
\end{tabular}

LSD Least Square Distance, PCA p-coumaric acid, DFA 8-5-I Diferulic acid 8-5-Linear, DFA8O4 Diferulic acid 8-O-4, DFAT Total diferulic acids, DFA 8-5 Diferulic acid 8-5, G Subunit, GLUA Glucuronic Acid

Means followed by a different letter are significantly different $(P \leq 0.05)$

\section{Discussion}

\section{Studying the variability in agronomic, cell wall and R.E.D} traits

\section{Agronomic traits}

The range obtained for days to silking and anthesis indicates that all inbred lines included in the panel were well adapted to the growing conditions at Pontevedra $\left(42^{\circ} 25^{\prime}\right.$ $\mathrm{N}, 8^{\circ} 38^{\prime} \mathrm{W}$ and $20 \mathrm{~m}$ above sea level). It is important to highlight two facts from the yield evaluations: (i) the value obtained for each inbred refers to the maximumpotential yield, not to the yield in a plot; and (ii) these values are for inbred lines, not being the standard material to be tested for yield, as it would be hybrid combinations.

\section{Cell wall composition}

Inbred lines differed significantly for every main cell wall fraction, with the exception of hemicellulose. Regarding lignin polymer, and in concordance with previous studies, $\mathrm{S}$ subunit represented the largest proportion, and $\mathrm{H}$ subunits the lowest proportion [44]. Variation for hydroxycinnmamic acids among the inbred lines was also found in accordance being, $p$-coumaric acid was the most abundant hydroxycinnamic acid, which is consistent with previous studies $[5,15]$.

We did not find variation for matrix monosaccharide composition among the 20 genotypes evaluated that could be consequence of lower variability in secondary than in primary cell walls [45]. However, the lack of differences for monosaccharide composition in the second internode does not exclude the existence of variation among inbreds at more specific stalk tissues (pith and rind) as it has been observed previously by Barros-Rios et al. [46].

\section{R.E.D traits}

Regarding ethanolic production we found variation for saccharification efficiency. Other researchers have studied the saccharification efficiency of several crops species following the same method and pre-treatment; and variability in saccharification efficiency among different genotypes was also found. Species like Miscanthus, switchgrass or sugarcane, are promising candidates for the industrial production of biofuel as they present high biomass yields (15-25 Mg/ha), broad geographic adaptation, superior carbon sequestration and efficient nutrient utilization [47]. However, these species cannot be readily implemented on a wide-commercial scale. In contrast, maize is the most important crop in terms of production, 1300 million tons of dry maize stover are produced worldwide [48]; and can potentially supply vast amounts of lignocellulose in the form of agricultural residues $(5 \mathrm{Mg} / \mathrm{ha})$ [47]. In view of the results obtained 
Table 5 Multiple linear regression stepwise model selection and equation for saccharification efficiency and digestibility of organic matter according to the cell wall composition in the internode of 20 inbred lines evaluated during two years

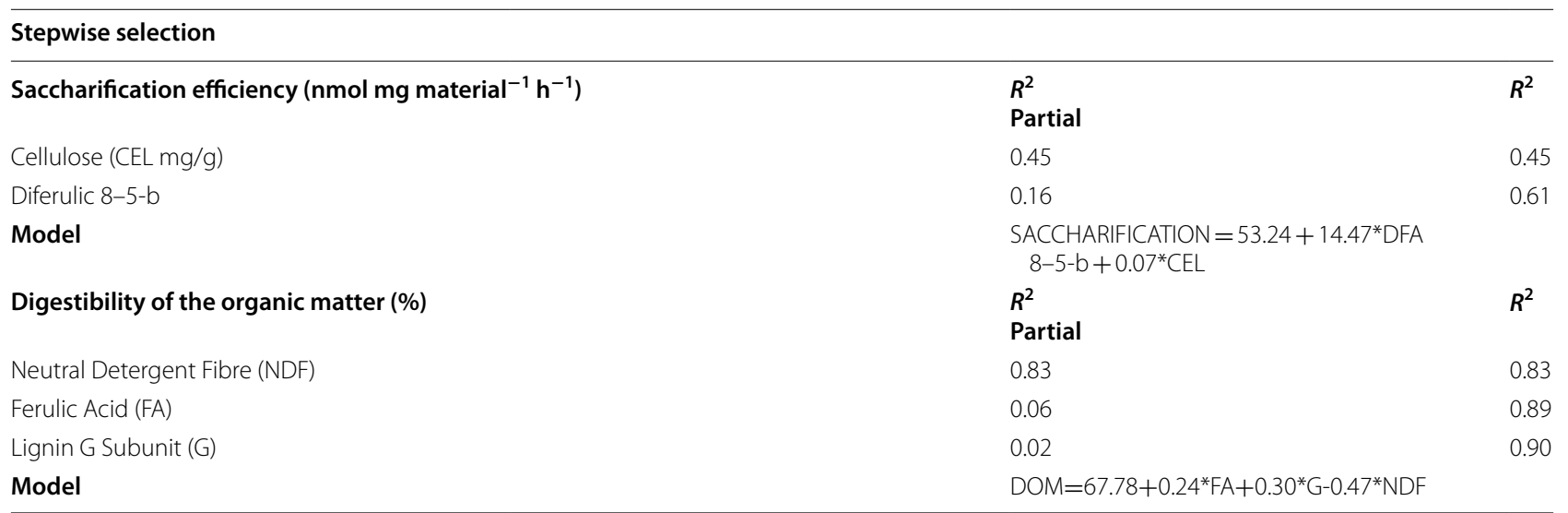

$R^{2}$ partial Percentage of the variance explained by each trait, $R 2$ Total percentage of the variance explained by the model

for saccharification efficiency in contrast to other crops, maize arises as an outstanding model able to contribute significantly to the energy industry's feedstock both in quality and quantity.

Contrarily to expectations, the parental inbreds of hybrids with high soluble sugar content in the stalk (C103, CO348, CO384, CO444 and CO442) did not show the most promising values for saccharification efficiency, except the inbred line CO442 [25]. Conversely, some other inbred lines could be identified as potential candidates to be base material in breeding programs for increasing the saccharification efficiency: A654, EC212, EP17, EP42 and F473. Four of these inbred lines are included in the European Flint Heterotic Group (EC212, EP17, EP42 and F473) and the last one in the Reid Group (A654), so that it is possible to obtain good heterosis for grain production, while getting high saccharification efficiency.

Regarding DOM, the rank obtained is in agreement with the previous values published for maize in vitro digestibility [49]. Digestibility of the organic matter was higher in maize than in sorghum, with values ranging between 40 and $45 \%$; rice straw, ranging from $23.6 \%$ to $36.9 \%$; and barley stems, ranging from 32 to $35 \%[50,51]$.

\section{Relationship among cell wall components and R.E.D. traits} Resistance to corn borer has been associated to shorter galleries produced by the larvae in the stalks [2]; In view of our results a resistant inbred line in the internode would present cell walls with low p-coumaric acid concentration and low hemicellulose content. Inbred lines showing cell walls with high cellulose content, and high diferulate cross-linking as opposed to cell wall reinforced by lignin may present high saccharification efficiency. By last, inbred lines with enhanced digestibility must have a cell wall poor in neutral detergent fibre and diferulic acid cross-links, combined with a lignin polymer richer in $G$ subunits.

Our results relate hemicellulose with pest resistance. Krakowsky et al. [52] suggested a positive correlation between European corn borer stalk tunnelling and stalk and sheath NDF adjusted for ADF. NDF adjusted represents the relatively digestible hemicellulosic fraction. Additionally, Terra et al. [53] found that hemicellulose is partly digested by the larvae of Erinnyis ello feeding on Euphorbia pulcherrima leaves, as opposed to other cell wall components. A larger proportion of hemicellulose could favour the attack of the insect, while other structural components involved in tissue strengthening, such as lignin, deter the larvae advance [54].

Regarding DOM, high concentration of fibres (cellulose, hemicellulose and lignin) directly affects digestibility by the limitation of the energy intake by the animals [55]. In agreement with our results, Wolf et al. [55] analysed two maize populations (with high and low concentrations of NDF, ADF, lignin, and silica) and found that the population exhibiting low range of NDF also showed greater digestibility.

A greater concentration of glucuronic acid was also detrimental for DOM. Hemicellulose could be a potential repository of fermentable sugars [56], but unlike cellulose, hemicelluloses are not chemically homogeneous. Maize fibre xylan is one of the complex heteroxylans containing $\beta-(1,4)$-linked xylose residues [57]. About $80 \%$ of the xylan backbone is highly substituted with monomeric side-chains of arabinose or glucuronic acid linked to O-2 and/or O-3 of xylose residues. The effect of hydrolytic enzymes used in processes such as DOM are influenced by the variation of the primary structure of the arabinoxylans [58]. Based on the works of Van 
Eylen et al. [59] and Appeldoorn et al. [60] reductions in the frequency of acetic acid, uronic acid and arabinose side groups in glucuronoarabinoxylans would concurrently lead to a reduction in the cell wall recalcitrance. The presence of more substitutions in the arabinoxylan chain, particularly glucuronic acids, could interfere the specific mode of action of hydrolytic enzymes, limiting this way the DOM.

PCA differed in concentration between susceptible and resistant inbred lines; susceptible lines presenting a higher concentration of $p$-coumaric acid. This result appears contradictory with previous results, as high concentration of $p$-coumaric acid has been related to resistance to corn borer attack [5]. On the contrary, higher concentrations of PCA are related with lower DMO. Most $p$-coumarate accretion occurs in tandem with lignification and its accumulation can be considered a relevant indicator of lignin deposition. In grasses, lignins are acylated (primarily syringyl units) at the $\gamma$-position by $p$-coumarates [61]. Acylation has a marked influence on the bonding mode of $\mathrm{S}$ lignin units, on the spatial organization of lignins and, consequently, on their capacity to interact with polysaccharides. It is known that syringyl type lignin forms a more linear structure, [62] with little or no branching and with a lesser degree of polymerization. This lignin structure protects larger proportion of the polysaccharides in the wall from digestion; thus reducing cell wall digestibility [62]. $S$ lignin has been involved in defence against biotic stresses [63-65]. At least in the materials evaluated S-type lignin, indirectly associated to more PCA acetylation, may favour borer susceptibility. Apparent inconsistencies between studies might be due to the type of tissues analysed; for example, in the current work, stalk (pith and rind) was analysed, while only pith tissues were used in previous studies [15, 24].

In our study, also in relation with lignin structure, lines included in the high digestibility group showed greater proportion of G subunits. Mechin et al. [3] observed a decreased $\mathrm{S} / \mathrm{G}$ ratio, thus a reduced proportion of subunits $\mathrm{S}$ in $b m 3$ mutants, characterized by its improved stover digestibility. They also observed that the decrease in the proportion of $\mathrm{S}$ subunit was balanced by an increase in proportion of G; which could be, among others, one of the reasons of the increased degradability in bm3 mutants, agreeing with our results.

Lignocellulosic polysaccharides, mainly cellulose (40\%), serve as principal substrate for fermentation of cell wall sugars in ethanol [40]; thereby, cell walls richer in cellulose have more sugars to potentially be fermented. Improving the relative content of cellulose was already one of the main strategies towards the development of advanced lignocellulosic feedstocks [18].
During lignification, the ferulic acid and diferulic esters form cross-links through the etherification of the phenolic hydroxyl group to lignin polymers, [66] forming a polysaccharide-lignin matrix that renders cell wall more recalcitrant to enzymatic hydrolysis [66]. The results obtained in the contrast analysis for DOM are consistent with this statement: the most digestible lines are the ones presenting a cell wall less cross-linked by diferulates. Conversely, our findings indicate that a greater concentration of ester diferulates can be associated with an enhanced saccharification efficiency of the maize stalk. However, as pre-treatments, before the saccharification, are essential to enhance the effectivity of hydrolytic enzymes, the pre-treatment used could be responsible for that unexpected association. Among the several types of pre-treatments that could be used, alkaline pre-treatment is appropriate for corn stover and other monocots due to its particular cell wall composition [67]. The cell walls of graminaceous monocots are known to contain alkali-labile ferulate ester cross-links within the hemicellulose [68], as well as high phenolic hydroxyl contents in their lignins, resulting in increased alkali solubility [69], rendering the cell wall highly susceptible to delignification by alkaline pretreatments [6]. As a consequence, mild alkali pre-treatment of grasses such as maize has shown substantial advantages, as these can be employed for both fractionating biomass and generating a pre-treated biomass that is highly amenable to enzymatic hydrolysis $[15,66]$. This may also involve cell wall plasticity, so a greater amount of crosslinking elements in the cell wall may replace the deposition of other structural elements, such as lignin, finally favouring deconstruction [70]. A cell wall where the structural reinforcement is mainly due to a greater crosslinking effect mediated by dimers could represent an improvement in the process of obtaining ethanol, considering that, among the samples pre-treatments, saponification, is usually included and would eliminate these compounds [71]. Li et al. [6] found, in a study of a subset of 26 inbred lines of maize, that the pre-treated cell-wall hydrolysis yields were positively correlated with the ferulate released by alkali pre-treatment, indicating that breaking of ferulate cross-links between cell- wall polymers is an important outcome of pre-treatment. This result reinforces the hypothesis that cell walls where the structural support is based in a higher cross-linkage by diferulates could be more favourable to sugar release, but only after the corresponding alkaline pre-treatment. The role of crosslink is still negative for saccharification if not pre-treated. On the other hand, a larger proportion of ester-link diferulates may indicate a lesser proportion of ether-linked diferulates bound to lignin, and therefore less recalcitrant cell walls. However, ether-linked 
diferulates cannot be precisely determined under the current wet chemistry procedures.

\section{Is it possible to identify a particular ideotype useful in R.E.D.?}

Our results show that it is very difficult to find a maize ideotype presenting a cell wall composition that fits the three requirements of R.E.D, as one combination of components would favour one use and negatively affects the other. For example, that is the case of the diferulic acid content, which affects cell wall digestibility and saccharification efficiency, or borer resistance and saccharification, both in opposite ways. Therefore, we could aim to obtain a putative genotype from this subset of lines with the best combination of cell wall compositional traits to be used in a particular usage. Despite this, among this subset of inbred lines, we found inbred lines that present high saccharification efficiency and high digestibility of the organic matter: EP42 and EC212; however, we must note that both are susceptible to corn borer attack.

\section{Conclusions}

Genotypic variation has been observed for agronomic, cell wall composition and saccharification efficiency in the set of 20 inbred lines analysed. The germplasm represented by these inbred lines is a potential source of variation that can be exploited in the improvement of biofuel production using maize as a resource.

It is not possible to define a cell wall ideotype that simultaneously fits the requirements for the three uses proposed. We have to settle for identifying the inbred lines with the better combination of cell wall traits for each final use of maize, to be used in future and specific breeding programs. According to these results, we can propose a maize cell wall ideotype to each specific area to be improved: (i) borers resistance in the internode may involve cell walls with low $p$-coumaric acid concentration and low hemicellulose content; (ii) saccharification efficiency must be improved by increasing the presence of cellulose and diferulates; (iii) and, to improve digestibility, cell wall must have poor neutral detergent fiber and diferulate cross-links, combined with a lignin polymer richer in $\mathrm{G}$ subunits.

\footnotetext{
Abbreviations

AAFC: Agriculture and Agri-Food Canada; ADF: Acid Detergent Fibre; ARA: Arabinose; ARAXYL: Ratio Arabinose/Xylose; AX: Arabinoxylan; BLUEs: Best Linear Unbiased estimators; bm: Briwn midrib; CAD: Cinnamyl Alcohol Dehydrogenase; CEL: Celullose; DFA 5-5: Diferulic Acid 5-5; DFA 8-5: Diferulic Acid 8-5; DFA 8-5-b: Diferulic Acid 8-5-Benzofuran; DFA 8-5-l: Diferulic Acid 8-5-Linear; DFA 8-0-4: Diferulic Acid 8-O-4; DFAT: Total Diferulic Acids; DOM: Digestibility of Organic Matter; FA: Ferulic Acid; FUC: Fucose; G: Subunit G; GAL: Galactose; GALA: Galacturonic acid; GCA: Good general combining ability; GLU: Glucose;
}

GLUA: Glucuronic Acid; H: Subunit H; HEMTOT: Percentage of Total Hemicellulose; IVDMD: In vitro Dry Matter Digestibility; IVNDFD: In vitro Neutal Detergent Fibre Digestibility; KL: Klason Lignin; LSD: Least Significance Difference; MAGIC: Multiparent-Advanced Generation Intercross; MAN: Mannose; NIRs: Near-Infrared Spectroscopy; NDF: Neutral Detergent Fibre; NSHEMICEL: Neutral Sugars from Hemicellulose; PCA: $p$-Coumaric Acid; PRIN: Principal Component; R.E.D: Pest Resistance, Ethanol production, forage Digestibility; RHA: Rhammanose; rp: Phenotypic Correlation; S: Subunit S; S:G: S:G ratio; SACC: Saccharification Efficiency; TL: Tunnel Length; TSHEMICEL: Total Sugar from Hemicellulose; UAHEMICEL: Uronic Acids from Hemicellulose; XYL: Xylose.

\section{Supplementary Information}

The online version contains supplementary material available at https://doi. org/10.1186/s12870-021-03040-3.

Additional file 1: Supplementary Table 1. Means for agronomic traits and yields evaluated in 20 inbred lines during two years. Supplementary Table 2. Means of cell wall polysaccharides and matrix monosaccharides in 20 inbred lines evaluated during two years. Supplementary Table 3. Means of Klason lignin, lignin monomeric composition in 20 inbred lines evaluated during two years. Supplementary Table 4. Means of cell wallbound hydroxycinnamates in 20 inbred lines evaluated during two years. Supplementary Table 5. Values for cell wall fibres in 20 inbred lines evaluated during two years. Supplementary Table 6 . Means for traits related to R.E.D evaluated in 20 inbred lines during for two years.

\section{Acknowledgements}

We are grateful to Prof. Simon J McQueen Mason for their support at the CNAP, University of York, UK. We thank Lana Reid for the transfer of the Canadian inbred lines, and the Dixon laboratory at University of North Texas for support with the lignin compositional analyses. We thank Dr. Pedro Revilla and Dr. Ana Butrón for the final proof read of the manuscript.

\section{Authors' contributions}

RAM, RS2 conceived and design the study. RAM, RS2, AL, participated in its design and carried out the field trial and participated in sample collection; $A L$, RAM, RS2 performed data analysis; AL wrote the manuscript; LDG, RS1, JBR and SP performed laboratory analysis and assisted in saccharification efficiency, lignin composition and NIRs determinations. AE and XCS, contributed significantly to the discussion of the manuscript. All authors read and approved the final manuscript.

\section{Funding}

This research has been developed in the frame of the 'Agri-Food Research and Transfer Centre of the Water Campus (CITACA) at the University of Vigo (Spain), which is economically supported by the Galician Government and in the Mlsión Biológica de Galicia-CSIC. It was funded by the "Plan Estatal de Ciencia y Tecnología de España" (projects RTI2018-096776-B-C21, and RTI2018-096776B-C22 co-financed with European Union funds under the FEDER program). A. López-Malvar's scholarship for the PhD fulfilment has been granted by University of Vigo and by a contract charged to the project RTI2018-096776-BC22. R. Santiago's postdoctoral contract "Ramón y Cajal" has been financed by the Ministry of Economy and Competiveness (Spain), Vigo University, and the European Social Fund. The funding body played no role in study design, data analysis, and manuscript preparation.

Availability of data and materials

The data sets used and/or analysed during the current study will be available upon request to the corresponding author.

\section{Declarations}

Ethics approval and consent to participate

Not applicable in this study.

\section{Consent for publication}

Not applicable in this study. 


\section{Competing interests}

The authors declare that they have no competing interests.

\section{Author details}

${ }^{1}$ Facultad, de Biología, Departamento de Biología Vegetal Y Ciencias del Suelo, Universidad de Vigo, As Lagoas Marcosende, 36310 Vigo, Spain. ${ }^{2}$ Agrobiología Ambiental, Calidad de Suelos Y Plantas (UVIGO), Unidad Asociada a La MBG (CSIC), Vigo, Spain. ${ }^{3}$ Misión Biológica de Galicia (CSIC), Pazo de Salcedo, Carballeira 8, 36143 Pontevedra, Spain. ${ }^{4}$ E.E. Forestales, Dpto. Ingenieria Recursos Naturales Y Medio Ambiente, 36005 Pontevedra, Spain. ${ }^{5}$ CNAP, Department of Biology, University of York, Heslington YO10 5DD, York, UK. ${ }^{6}$ Dpto. Ingeniería Y Ciencias Agrarias, Área de Fisiología Vegetal, Universidad de León, Campus de Vegazana s/n, 24071 León, Spain. ${ }^{7}$ BioDiscovery Institute and Department of Biological Sciences, University of North Texas, 1155 Union Circle, \#311428, Denton, TX 76203-5017, USA. ${ }^{8}$ Laboratorio Interprofesional Galego de Análise Do Leite (LIGAL), Mabegondo, 15318 A Coruña, Abegondo, Spain.

Received: 30 July 2020 Accepted: 14 May 2021

Published online: 02 June 2021

\section{References}

1. Fry SC. Cross-linking of matrix polymers in the growing cell walls of angiosperms. Annu Rev Plant Physiol. 1986;37:165-86.

2. Butrón A, Malvar RA, Cartea ME, Ordás A, Velasco P. Resistance of maize inbreds to pink stem borer. Crop Sci. 1999;39:102-7.

3. Méchin V, Argillier O, Menanteau V, Barrière Y, Mila I, Rollet B, et al. Relationship of cell wall composition to in vitro cell wall digestibility of maize inbred line stems. J Sci Food Agric. 2000;80:574-80.

4. Barrière Y, Méchin V, Riboulet C, Guillaumie S, Thomas J, Bosio M, et al. Genetic and genomic approaches for improving biofuel production from maize. Euphytica. 2009;170:183-202.

5. Santiago R, Butrón A, Reid LM, Arnason JT, Sandoya G, Souto XC, et al. Diferulate content of maize sheaths is associated with resistance to the Mediterranean corn borer Sesamia nonagrioides (Lepidoptera: Noctuidae). J Agric Food Chem. 2006;54:9140-4.

6. Li M, Heckwolf M, Crowe JD, Williams DL, Magee TD, Kaeppler SM, et al. Cell-wall properties contributing to improved deconstruction by alkaline pre-treatment and enzymatic hydrolysis in diverse maize (Zea mays L.) lines. J Exp Bot. 2015;66:4305-15.

7. Santiago R, Sandoya G, Butrón A, Barros J, Malvar RA. Changes in phenolic concentrations during recurrent selection for resistance to the Mediterranean corn borer (Sesamia nonagrioides Lef.). J Agric Food Chem. 2008;56:8017-22.

8. Buendgen MR, Coors JG, Grombacher AW, Russell WA. European corn borer resistance and cell wall composition of tree maize populations. Crop Sci. 1990;30:505-10.

9. Bergvinson DJ, Arnason JT. Phytochemical changes during recurrent selection for resistance to the European corn borer. Crop Sci. 1997;37:1567.

10. Sarath G, Dien B, Saathoff AJ, Vogel KP, Mitchell RB, Chen H. Ethanol yields and cell wall properties in divergently bred switchgrass genotypes. Bioresour Technol. 2011;102:9579-85.

11. Sarath G, Akin DE, Mitchell RB, Vogel KP. Cell-wall composition and accessibility to hydrolytic enzymes is differentially altered in divergently bred switchgrass (Panicum virgatum L.) genotypes. Appl Biochem Biotechnol. 2008;150:1-14.

12. Vogel KP, Mitchell RB, Sarath G, Jung HG, Dien BS, Casler MD. Switchgrass biomass composition altered by six generations of divergent breeding for digestibility. Crop Sci. 2013;53:853-62.

13. Bertrand A, Castonguay Y, Duceppe M. Selection for improved saccharification efficiency in alfalfa stems assessed by enzyme-released glucose. 2013:325-6.

14. Barros-Rios J, Malvar RA, Jung HJG, Bunzel M, Santiago R. Divergent selection for ester-linked diferulates in maize pith stalk tissues. Effects on cell wall composition and degradability. Phytochemistry. 2012;83:43-50. https://doi.org/10.1016/j.phytochem.2012.07.026.

15. Barros-Rios J, Malvar RA, Jung HJG, Santiago R. Cell wall composition as a maize defense mechanism against corn borers. Phytochemistry. 2011;72:365-71. https://doi.org/10.1016/j.phytochem.2011.01.004.
16. Jung HG, Mertens DR, Phillips RL. Effect of reduced ferulate-mediated lignin/arabinoxylan cross-linking in corn silage on feed intake, digestibility, and milk production. J Dairy Sci. 2011;94:5124-37. https://doi.org/ 10.3168/jds.2011-4495.

17. Barrière $Y$, Argillier $O$, Barrière $Y$, Brown-midrib OA, Sciences EDP. Brown-midrib genes of maize : a review to cite this version: $\mathrm{HAL}$ Id : hal-00885517 Brown-midrib genes of maize. Agronomie. 1993;13:865-76.

18. Jung HJG, Samac DA, Sarath G. Modifying crops to increase cell wall digestibility. Plant Sci. 2012;185-186:65-77. https://doi.org/10.1016/j. plantsci.2011.10.014.

19. Fu C, Xiao X, Xi Y, Ge Y, Chen F, Bouton J, et al. Downregulation of cinnamyl alcohol dehydrogenase (CAD) leads to improved saccharification efficiency in switchgrass. Bioenergy Res. 2011;4:153-64.

20. Butrón A, Santiago R, Cao A, Samayoa L, Malvar R. QTLs for resistance to fusarium ear rot in a multiparent advanced generation intercross (MAGIC) maize population. Plant Dis. 2019;103:897-904.

21. Jiménez-Galindo JC, Malvar RA, Butrón A, Santiago R, Samayoa LF, Caicedo $M$, et al. Mapping of resistance to corn borers in a MAGIC population of maize. BMC Plant Biol. 2019;19:1-17

22. Yi Q, Malvar RA, Álvarez-Iglesias L, Ordás B, Revilla P. Dissecting the genetics of cold tolerance in a multiparental maize population. Theor Appl Genet. 2020;133:503-16.

23. Butrón A, Samayoa F, Santiago R, Malvar RA. Selection efficiency of tunnel length and stalk breakage to obtain maize inbred lines resistant to stem borer attack. Euphytica. 2014;197:295-302.

24. Santiago R, Butron A, Arnason JT, Reid LM, Souto XC, Malvar RA. Putative role of pith cell wall phenylpropanoids in Sesamia nonagrioides (Lepidoptera: Noctuidae) resistance. J Agric Food Chem. 2006;54:2274-9.

25. Reid LM, Morrison MJ, Zhu X, Jindal KK, Ma BL. High stalk sugar corn: a potential biofuel crop for Canada. Agron J. 2015;107:475-85.

26. Martínez Fernández A. Los pastos: nuevos retos, nuevas oportunidades. 2013.

27. Mélida H, Encina A, Álvarez J, Acebes JL, Caparrós-Ruiz D. Unraveling the biochemical and molecular networks involved in maize cell habituation to the cellulose biosynthesis inhibitor dichlobenil. Mol Plant. 2010;3:842-53.

28. Updegraff DM. Semimicro determination of cellulose inbiological materials. Anal Biochem. 1969;32:420-4.

29. Dische Z. Color reactions of carbohydrates. In: Whistler RL, Wolfrom MLE, editors. Methods in carbohydrate chemistry, vol. 1. New York: Academic Press; 1962. p. 475-514.

30. Dubois M, Gilles K, Hamilton J, Rebers P, Smith F. Colorimetric method for determination of sugars and related substances. Anal Chem. 1956;28:350-6. https://doi.org/10.1021/ac60111a017.

31. Blumenkrantz N, Asboe-Hansen G. New method for quantitative determination of uronic acids. Anal Biochem. 1973;54:484-9.

32. Jones L, Milne JL, Ashford D, McQueen-Mason SJ. Cell wall arabinan is essential for guard cell function. Proc Natl Acad Sci U S A. 2003;100:11783-8.

33. Dence CW. The determination of Lignin. Berlin: Springer; 1992. p. 33-61.

34. Barros J, Escamilla-Trevino L, Song L, Rao X, Serrani-Yarce JC, Palacios MD, et al. 4-Coumarate 3-hydroxylase in the lignin biosynthesis pathway is a cytosolic ascorbate peroxidase. Nat Commun. 2019;10:1-11. https://doi. org/10.1038/s41467-019-10082-7.

35. Santiago R, López-Malvar A, Souto C, Barros-Ríos J. Methods for determining cell wall-bound phenolics in maize stem tissues. J Agric Food Chem. 2018:66:1279-84

36. Waldron KW, Parr AJ, Ng A, Ralph J. Cell wall esterified phenolic dimers: Identification and quantification by reverse phase high performance liquid chromatography and diode array detection. Phytochem Anal. 1996;7:305-12.

37. Shenk JS, Westerhaus MO. Routine operation, calibration, development and network system management manual. Silver Spring: NIRSystems Inc.; 1995.

38. Van Soest PJ, Robertson JB. Analysis of forages and fibrous foods. Ithaca: Cornell Un; 1985

39. Goering HK, Van Soest PJ. Forage fiber analysis. In: Agricultural handbook no.379. Washington, DC: US Department of Agriculture; 1970. p. 1-20.

40. Gomez LD, Whitehead C, Barakate A, Halpin C, McQueen-Mason SJ. Automated saccharification assay for determination of digestibility in 
plant materials. Biotechnol Biofuels. 2010;3:23. https://doi.org/10.1186/ 1754-6834-3-23.

41. Tilley JMA, Terry RA. A two-stage technique for the in vitro digestion of forage crops. Grass Forage Sci. 1963;18:104-11.

42. Alexander $\mathrm{RH}, \mathrm{McG}$ cwan $\mathrm{M}$. The routine determination of in vitro digestibility of organic matter in forages-an investigation of the problems associated with continuous large-scale operation. Grass Forage Sci. 1966;21:140-7.

43. SAS/STAT; SAS Institute Inc.: Cary, 2007.

44. Grabber JH, Ralph J, Lapierre C, Barrière Y. Genetic and molecular basis of grass cell-wall degradability. I. Lignin-cell wall matrix interactions. Comptes Rendus-Biol. 2004;327:455-65.

45. Carpita NC, Mccann MC. Biochemistry and molecular biology of plants. Buchanan. 2000;52-108.

46. Barros-Rios J, Santiago R, Malvar RA, Jung HJG. Chemical composition and cell wall polysaccharide degradability of pith and rind tissues from mature maize internodes. Anim Feed Sci Technol. 2012;172:226-36. https://doi.org/10.1016/j.anifeedsci.2012.01.005.

47. Torres AF, Van Der Weijde T, Dolstra O, Visser RGF, Trindade LM. Effect of maize biomass composition on the optimization of dilute-acid pretreatments and enzymatic saccharification. Bioenerg Res. 2013;6:1038-51.

48. Youngs $\mathrm{H}$, Somerville C. Development of feedstocks for cellulosic biofuels. F1000 Biol Rep. 2012; 4.

49. Flores Calvete G, González-Arráez A, Castro González J, Castro García P, Fernández Lorenzo, B Valladares Alonso J, Cardelle Campos M. Prediction of herbage and maize silages in vivo organic matter digestibility by laboratory methods. Rev Pastos. 2003.

50. Vadivelooa J, Fadelb JG. Compositional analyses and rumen degradability of selected tropical feeds. Anim Feed Sci Technol. 1992;37:265.

51. Capper BS. Genetic variation in the feeding value of cereal straw. Anim Feed Sci Technol. 1988:21:127-40

52. Krakowsky MD, Lee M, Holland JB. Genotypic correlation and multivariate QTL analyses for cell wall components and resistance to stalk tunneling by the European corn borer in maize. Crop Sci. 2007;47:485-90.

53. Terra WR, Valentin A, Santos CD. Utilization of sugars, hemicellulose, starch, protein, fat and minerals by Erinnyis ello larvae and the digestive role of their midgut hydrolases. Insect Biochem. 1987;17:1143-7.

54. Barros-Rios J, Santiago R, Jung HJG, Malvar RA. Covalent cross-linking of cell-wall polysaccharides through esterified diferulates as a maize resistance mechanism against corn borers. J Agric Food Chem. 2015;63:2206-14.

55. Wolf DP, Coors JG, Albrecht KA, Undersander DJ, Carter PR. Forage quality of maize genotypes selected for extreme fiber concentrations. Crop Sci. 1993;33:1353-9.

56. Bera AK, Ho NWY, Khan A, Sedlak M. A genetic overhaul of Saccharomyces cerevisiae $424 \mathrm{~A}(\mathrm{LNH}-\mathrm{ST})$ to improve xylose fermentation. J Ind Microbiol Biotechnol. 2011;38:617-26

57. Saha BC, Bothast RJ. Pretreatment and enzymatic saccharification of corn fiber. Appl Biochem Biotechnol - Part A Enzym Eng Biotechnol. 1999;76:65-77.

58. Berrin JG, Juge N. Factors affecting xylanase functionality in the degradation of arabinoxylans. Biotechnol Lett. 2008;30:1139-50.

59. Van Eylen D, van Dongen F, Kabel M, de Bont J. Corn fiber, cobs and stover: enzyme-aided saccharification and co-fermentation after dilute acid pretreatment. Bioresour Technol. 2011;102:5995-6004. https://doi. org/10.1016/j.biortech.2011.02.049.

60. Appeldoorn MM, Kabel MA, Van Eylen D, Gruppen H, Schols HA. Characterization of oligomeric xylan structures from corn fiber resistant to pretreatment and simultaneous saccharification and fermentation. J Agric Food Chem. 2010;58:11294-301.

61. Ralph J, Hatfield RD, Quideau S, Helm RF, Grabber JH, Jung HJG. Pathway of p-Coumaric acid Incorporation into maize lignin as revealed by NMR. J Am Chem Soc. 1994;116:9448-56.

62. Kishimoto T, Uraki Y, Ubukata M. Easy synthesis of $\beta-0-4$ type lignin related polymers. Org Biomol Chem. 2005;3:1067-73.

63. Zhao $Q$, Wang $H$, Yin $Y, X u Y$, Chen F, Dixon RA. Syringyl lignin biosynthesis is directly regulated by a secondary cell wall master switch. Proc Natl Acad Sci U S A. 2010;107:14496-501.

64. Ma QH, Zhu HH, Qiao MY. Contribution of both lignin content and sinapyl monomer to disease resistance in tobacco. Plant Pathol. 2018;67:642-50.
65. Gesteiro N, Butrón A, Estévez S, Santiago R. Unraveling the role of maize (Zea mays L.) cell-wall phenylpropanoids in stem-borer resistance. Phytochemistry. 2021;185:112683.

66. Scalbert A, Monties B, Lallemand JY, Guittet E, Rolando C. Ether linkage between phenolic acids and lignin fractions from wheat straw. Phytochemistry. 1985;26:1359-62.

67. Silverstein RA, Chen Y, Sharma-Shivappa RR, Boyette MD, Osborne J. A comparison of chemical pretreatment methods for improving saccharification of cotton stalks. Bioresour Technol. 2007;98:3000-11.

68. Hatfield RD, Wilson JR, Mertens DR. Composition of cell walls isolated from cell types of grain sorghum stems. J Sci Food Agric. 1999;79:891-9.

69. Lapierre C, Jouin D, Monties B. On the molecular origin of the alkali solubility of Gramineae lignins. Phytochemistry. 1989;28:1401-3.

70. Chabannes M, Barakate A, Lapierre C, Marita JM, Ralph J, Pean M, et al. Strong decrease in lignin content without significant alteration of plant development is induced by simultaneous down-regulation of cinnamoyl CoA reductase (CCR) and cinnamyl alcohol dehydrogenase (CAD) in tobacco plants. Plant J. 2001;28:257-70.

71. Liu T, Williams DL, Pattathil S, Li M, Hahn MG, Hodge DB. Coupling alkaline pre-extraction with alkaline-oxidative post-treatment of corn stover to enhance enzymatic hydrolysis and fermentability. Biotechnol Biofuels. 2014;7:1-12.

\section{Publisher's Note}

Springer Nature remains neutral with regard to jurisdictional claims in published maps and institutional affiliations. 